\title{
リハビリテーション医学の天動説と地動説 \\ The Ptolemaic Theory and the Heliocentric Theory of Rehabilitation Medicine
}

\author{
○滝沢茂男 ${ }^{1}$ ， 木村哲彦 ${ }^{2}$ \\ 1. 文部科学省指定研究機関バイオフィリア研究所, 2, 国際医療福祉大学 \\ OTAKIZAWA, Shigeo ${ }^{1}$ and Tetsuhiko Kimura ${ }^{2}$ \\ 1. Biophilia Institute, designated by MEXT, 2, International University of Health and Welfare
}

\begin{abstract}
1. はじめに
現在のリハビリテーション(以後リハ) について, 日本リ八医学 会などの 5 学会と厚生労働省の 3 研究班からなる合同ガイドライ ン委員会 ${ }^{1)}$ は,「我が国において, 脳卒中患者の多くがリ八医 療の対象となり, 事実, 演たきりの原因の約 $30 \%$ 脳卒中で, 後遣症に悩む患者数は約 170 万人と推計される.」と報告した. わが国では平成 18 年 4 月よりリ八診療日数が短縮された. 報 道はリ八診療日数の短縮が患者に悪影響を与える, としてい るものが目立つが, リ八診療日数は世界的に減少している ${ }^{2)}$. 我々はリ八医療において，診療日数の短縮が悪影響を与える のではなく, 現在のリ八医療の手法に問題があると考察する. リ八医学は障害の受容の概念が一側面にあり，リ八実施後， 結果として拘縮を残し, 歩行困難で寝たきりになる例が多い. この点に関して, 委員会1)リ八班は「脳卒中リ八医学・医療 での治療法, 訓練手技などは, ・・・全般的にはエビデンス の面からは妥当性が十分とはいえず，今後のさらなる研究が 待たれるといえよう」との意見を述べている. 我々もこれま でこの視点に立って研究を進めている.
\end{abstract}

\section{2. 神経筋促通法}

委員会 ${ }^{1)}$ は 1960〜1990 年の 30 年間のエビデンスに基づい たリ八の論文 36 編を調査した. 調査された論文から, 神経筋促 通法の代表的な手法 Facilitation Techniques と筋力増強, 可 動域訓練, 動作訓練などの旧来の手法による結果を対比すると, 前者が後者より効果が見られたとするものはほとんどない.

\section{3. 天動説(厚生労做科学研究審査官の意見)}

リ八医療の革新を期して,「創動運動による効果的・効率 的なリ八技術の確立を図る.」ため, 厚生労働科学研究費を 申請したが，学術的評価点数 5 点中・ 1 点 (平均 3.2)「『評価 できる点, 推進できる点』なし」であった，意見交換を求め たが今日まで回答は皆無である。「研究の意義も私には理解 できない.」や，筆者が研究分担者として創動運動機序解明 のための実施済み研究に対し,「応募説明の文中には文部科学 省の研究費を使用して騒動 (創動) 運動に関する研究が進行中 であるかの文章があるが，業績中の記載と一致しているとは 考えられない.」との評もなされた．それらの研究分担者で ある筆者から見ると, 恰もコペルニクスの地動説を, キリス 卜教会の常識である天動説で抑圧した故事に類する。

\section{4. 明らかになっている事实}

Jaime Imitola ら 3)のマウスによる実験から, 損傷を受けたか, あるいは炎症を起こしたニューロン組織からケモカイン (Chemokine) という物質が分泌され，その誘導により神経幹細 胞が誘引されてくることが明らかになった. 神経幹細胞が組織実 質を通じて非定型的経路に沿って移動することは以前から知ら れていたが, 彼らは, 正確に方向性を持って中枢神経系の損傷 部位まで長距離移動する可能性を報告している. Jill Whitallら 4)は, 片麻瘴上腕の訓練に両側性訓練を行わせ, 平均 4 年前に 脳卒中を発症した者にも, 一定の効果があった, と報告している. トレーニングを受けた患者 9 例中 6 例 $(67 \%)$ で脳の新たな部位 が活性化され, その大部分は健常側であり, 新たな経路が形成 されたように見受けられた.これに対して，患側の腕のみ治療を
受けた群では, 新たな活性化部位は認められなかった, とした.

\section{5. 地動説(創動運動とプログラム化されたリハの効果)}

創動運動とプログラム化リハ5)の効果は, (1)㾏性の出現が少 なかった. 歩行不可に陷つてから，6ケ月を過ぎた旧い例にも歩 行可能になった例が少なくなかった. 80 歳以上の高齢者にも利 用でき効果的であった, などである, その報告は牛澤ら,6), 滝沢 ら,7)が行った. また牧田ら ${ }^{8)}$ は, 介護老人保健施設における無作 為比較対象試験を実施し有効性を認め, 報告している.

\section{6. 今後に}

1. はじめにを考察すると,介護費用の多くが現在行われて いるリ八医療の結果としての負担であることが認識できる. 超高齢社会を，日本国民ばかりでなく長寿を得た諸国民にと って持続可能なものにするために「障害の受容」から「障害 の克服」を可能にするリ八医療に革新し，より多くの高齢者 障害者が自立生活可能になることが望まれる. そのために, 現在進められているリ八医療システムや構築されている学問 体系が「他動運動」を中心としていることから，学問領域を 構成し, 構築している受益者にとって既得権益を侵すとの視 点で,「障害の受容から障害の克服」を実現する創動運動研究 を抑圧してはならない. 天動説で地動説を抑圧してはならな い. 人口ピラミッドの逆転による社会崩壊を目前にし, 歷史 の証明に委ねる時間は残されていないことを知るべきである。

\section{7. 参考文献}

1）篠原幸人, 他：脳卒中治療ガイドライン、2004, 協和企 画 (東京)

2) 01sen GG. : Rehab is under the gun again. Rehab Management, 2000 Jun-Jul;13(5):50-2.

3) Imitola $\mathrm{J}$, et al: Directed migration of neural stem cells to sites of CNS injury by the stromal cel1-derived factor 1-alpha/CXC chemokine receptor 4 pathway. Proc Nat1 Acad Sci U S A . 2004 ; 101:18117-22

4) Jill Whitall, et al: Repetitive Bilateral Arm Training With Rhythmic Auditory Cueing Improves Motor Function in Chronic Hemiparetic Stroke. Stroke 2000;31:2390

5) Takizawa S, Takizawa K: METHOD FOR MANAGING EXERCISE FOR FUNCTION RECOVERY AND MUSCLE STRENGTHENING, US Patent 7, 153, 250, 2006

6) Kenji Ushizawa, et al: Statistical Evaluation of Rehabilitation to the Disabled Elderly based Takizawa-Program, Biophilia Rehabilitation Journal, 2-1, p71-80, 2004,

7) Takizawa, S: Keeping the Elderly in Motion, Reha. Management international, Los Angels, Medical World Communications, 48, 2000

8) Makita M, et al: Randomized Controlled Traial to Evaluate Effectivenss of Exercise Therapy (Takizawa Program) for Frail Elderly, Environmental Health and Preventive Medicine 11, 5: 221-227, Sep. 2006 